\title{
Leydig cell number and function in the adult cynomolgus monkey (Macaca fascicularis) is increased by daily hCG treatment but not by daily FSH treatment
}

\author{
K. J. Teerds $\uparrow$, F. F. G. Rommerts*, H. J. G. van de Kant and D. G. de Rooij \\ Department of Cell Biology, Medical School, State University of Utrecht, The Netherlands; and \\ *Department of Biochemistry, Division of Chemical Endocrinology, Erasmus University, \\ Rotterdam, The Netherlands
}

\begin{abstract}
Summary. Daily treatment of adult cynomolgus monkeys with 450 i.u. hCG for 16 days resulted in a significant $163 \%$ increase in the number of Leydig cells, and a 9-fold rise in plasma testosterone concentrations. The number of proliferating Leydig cells was very low, even after 16 days of treatment with hCG. Daily FSH administration ( 2 injections of 15 i.u. per day) did not have any effect on the number of Leydig cells or plasma testosterone values. It can be concluded, therefore, that in adult cynomolgus monkeys daily hCG treatment results in an increase in the number of Leydig cells, which is mainly caused by the differentiation of precursor cells. Since plasma testosterone concentrations were increased to an even higher extent, the steroid production per Leydig cell was also stimulated.
\end{abstract}

Keywords: Leydig cells; hCG; FSH; adult cynomolgus monkey

\section{Introduction}

The administration of human chorionic gonadotrophin (hCG) to rats and primates results in a rise of plasma testosterone concentrations (Chemes et al., 1976, 1985; Saez \& Forest, 1979; Smals et al., 1979; Nankin et al., 1980). In rats, hCG also causes an increase in the number of Leydig cells (Christensen \& Peacock, 1980; Teerds et al., 1988). However, some contradictory results have been reported as to whether hCG treatment of primates also results in an increase in the number of Leydig cells (de Kretser, 1967; Heller \& Leach, 1971).

In the immature rat, FSH treatment can result in an increase in the number of Leydig cells and a stimulation of steroidogenesis (Kerr \& Sharpe, 1985a, b; Teerds et al., 1989). Furthermore, if the testis and the Leydig cells of adult rats are allowed to regress after hypophysectomy, FSH alone can enhance Leydig cell function (El Safoury \& Bartke, 1974; McNeilly et al., 1979; Shaw et al., 1979). It is not clear whether FSH can also affect Leydig cells in intact adult mammals.

The present study is an investigation of the effects of daily hCG or FSH treatment on the number of Leydig cells and their function in the adult cynomolgus monkey.

\section{Materials and Methods}

Materials. The hCG (Pregnyl) was obtained from Organon, Oss, The Netherlands. Follicle-stimulating hormone (FSH, Metrodin) was a gift from Pharma Import/Serono, Haarlem, The Netherlands. The LH contamination in this

$\Varangle$ Present address: Department of Cell Biology, Veterinary School, Yalelaan 1, P.O. Box 80.157, 3508 TD Utrecht, The Netherlands. 
FSH preparation was $<1 \% .\left[{ }^{3} \mathrm{H}\right]$ thymidine was obtained from the Radiochemical Centre, Amersham, UK (sp. act. $40 \mathrm{Ci} / \mathrm{mmol}$ ). Kodak NTB-2 dipping emulsion (Eastman/Kodak, Rochester, NY, USA) was used for autoradiography.

Treatment of animals. The adult male cynomolgus monkeys (Macaca fascicularis) weighed $6-7 \mathrm{~kg}$ and were obtained from the Laboratory of Comparative Physiology, Utrecht, The Netherlands, and the National Institute of Public Health and Environmental Protection, Bilthoven, The Netherlands.

One group of 6 monkeys received one daily intramuscular (i.m.) injection of 450 i.u. hCG at about 17:00 h for 16 days. The other group of 6 monkeys received two daily i.m. injections of 15 i.u. FSH at about $08: 30 \mathrm{~h}$ and $17: 00 \mathrm{~h}$ for 16 days. From each monkey, a testicular biopsy was taken 2 weeks before and within $5-18 \mathrm{~h}$ after the last FSH or hCG injection. The biopsies were taken from the right and the left testis alternately.

Tissue preparation. To study the $\left[{ }^{3} \mathrm{H}\right]$ thymidine incorporation by interstitial cells, some biopsies were placed in an incubation flask, containing $5 \mathrm{ml}$ modified Eagles Minimal Essential Medium to which $10 \%$ fetal calf serum was added, as described by Kluin et al. (1983). Briefly, the tissue was incubated in a shaking waterbath at $32^{\circ} \mathrm{C}$. After a preincubation period of $30 \mathrm{~min},\left[{ }^{3} \mathrm{H}\right]$ thymidine $(3 \mu \mathrm{Ci} / \mathrm{ml})$ was added. After incubation for $60 \mathrm{~min}$ in the presence of $\left[{ }^{3} \mathrm{H}\right]$ thymidine, the fragments were washed and fixed in Bouin's fluid.

After dehydration, the material was embedded in Technovit 7100 plastic (Kulzer and Co. GmbH, Wehrheim, FRG), a glycol methacrylate. Sections were cut at $5 \mu \mathrm{m}$ and stained by the periodic acid-Schiff (PAS) technique and Gill's haematoxylin (Polysciences Inc., Warrington, PA, USA). The autoradiographs were coated with dipping emulsion after staining according to the PAS technique. After 4-6 weeks of exposure at $4^{\circ} \mathrm{C}$, the slides were developed and stained with Gill's haematoxylin.

Cell counts. Nuclei of Leydig cells were recognized by their more or less spherical shape and the presence of a spherical nucleolus. Nuclei of macrophages were identified by their often irregular shape and slightly pink (PASpositive) staining cytoplasm. The nuclei of Leydig cells in which a nucleolus was present, macrophages, smooth muscle cells and endothelial cells belonging to the blood vessels, and the remaining interstitial cells that could not be identified as one of these cell types, were counted. Nuclei of Leydig cells in which the nucleolus was not visible in the cross-section were not counted as such. Cell counts were carried out for testis tissue from at least 4 monkeys.

The nuclear and nucleolus diameters of at least 135 Leydig cells in the control biopsies and after hCG or FSH treatment were measured. To avoid measurements of nuclear and nucleolar caps, only those nuclei and nucleoli were measured that had their greatest part included in the section. For each treatment the mean nuclear diameter and the mean nucleolus diameter of Leydig cells were calculated. By dividing the mean nuclear diameter by the mean nucleolus diameter, it was possible to calculate a nucleus/nucleolus ratio. A requisite when using this histometric method is that the nuclei and nucleoli of the Leydig cells are spherical, and the nucleolus is located more or less in the centre of the nuclear cross-section. This is nearly always the case in monkey Leydig cells. After extrapolation an estimation could be given of the actual number of Leydig cells and possible Leydig cell precursors (see 'Results').

Nuclei from Sertoli cells were also counted when the nucleolus was present in the nuclear cross-section. Cell counts were performed in random testicular areas in at least 3 different sections until 1000 Sertoli cells were scored. All interstitial cell numbers were expressed per 1000 Sertoli cells, according to the method of Heller et al. (1971). Since it has been demonstrated that the number of Sertoli cells in the adult animal does not undergo any changes, not even after treatment with gonadotrophins, it was not necessary to apply corrections for changes in the number of Sertoli cells (Steinberger \& Steinberger, 1977).

Hormone measurement. Blood samples were collected from all the monkeys before hormone treatment (control value), and about $5 \mathrm{~h}$ (FSH) to $18 \mathrm{~h}$ (hCG) after the last hormone injection. Plasma testosterone concentrations were assayed using the radioimmunoassay method as described by Verjans et al. (1973). Intra- and interassay coefficients of variation were 8.1 and $11.8 \%$, and the sensitivity was $<50 \mathrm{pg}$.

Student's $t$ test for paired data was used for statistical analysis.

\section{Results}

There was no difference in the nuclear morphology of the Leydig cells present in the control biopsies, and after hCG or FSH treatment of the monkeys (Fig. 1).

The mean nuclear diameter and the mean diameter of the nucleoli of Leydig cells from control, hCG and FSH treated cynomolgus monkeys were not significantly different $(8.55 \pm 0.60$, $8.74 \pm 0.60,8.50 \pm 0.67 \mu \mathrm{m}$, and $2.15 \pm 0.33,2.23 \pm 0.13,2.15 \pm 0.20 \mu \mathrm{m}$, respectively, mean \pm s.d.). Therefore, it was not necessary to apply corrections for changes in nuclear and nucleolar diameter of Leydig cells as a result of hormonal treatment.

By dividing the mean nuclear diameter of the Leydig cells by the mean diameter of the nucleolus it was possible to calculate a nucleus/nucleolus ratio. This ratio in control biopsies and after hCG or FSH treatment was $4.01 \pm 0.07,3.93 \pm 0.05$ and $4.00 \pm 0.08$ respectively (mean \pm s.d.) to 1 . This ratio indicates that the actual number of Leydig cells (henceforth called relative number of 


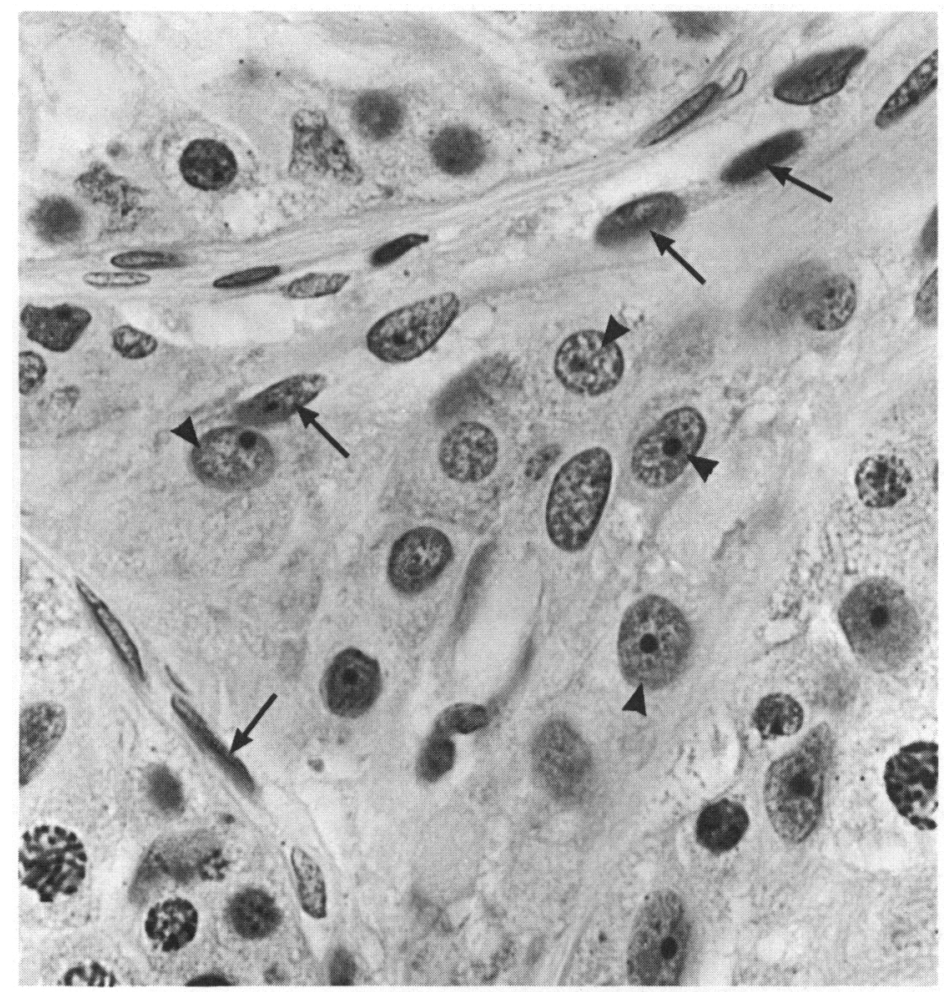

Fig. 1. Interstitial tissue in monkey testis after 16 days of hCG treatment. Leydig cells with a nucleolus present in the nuclear cross-section were often found (arrowheads). Possible Leydig cell precursors are indicated by arrows. $\times 1517$.

Leydig cells) was therefore approximately 4 times higher than the counted number of Leydig cells in which a nucleolus was present. Furthermore, after subtracting the relative number of Leydig cells from the total number of interstitial cells (Leydig cells with a nucleolus plus the remaining interstitial cells, see 'Materials and Methods'), an estimation could be given of the number of cells that was left and which might belong to the category of possible Leydig cell precursors.

After 16 days of hCG treatment, the relative number of Leydig cells had increased up to $163 \%$ of the control value (Table 1). No Leydig cells in mitosis (metaphase or anaphase) were observed in the control biopsies and after hCG treatment. The number of Leydig cells that had incorporated $\left[{ }^{3} \mathrm{H}\right]$ thymidine after hCG treatment was $<1$ per 1000 Sertoli cells. No labelled Leydig cells could be detected in control biopsies.

The labelling index of the remaining interstitial cells (including the possible Leydig cell precursors) increased as a result of the daily hCG treatment $(P<0.05)$. In control biopsies, the labelling index was $0.15 \pm 0.02 \%$, and in tissue from hCG-treated monkeys it was $0.35 \pm 0.07 \%$.

The number of possible Leydig cell precursors after hCG treatment was not significantly different from the control number (Table 1).

Daily FSH administration had no effect on the relative number of Leydig cells, or on the number of possible Leydig cell precursors (Table 1). No Leydig cells or other interstitial cells in mitosis could be detected under these experimental conditions.

Plasma testosterone concentrations (mean \pm s.e.m.) were approximately 9-fold higher after hCG treatment than before treatment $(202 \cdot 3 \pm 21 \cdot 3$ and $23.4 \pm 3.8 \mathrm{nmol} / 1$ respectively, $\mathrm{N}=6)$, but FSH treatment for 16 days had no effect $(19 \cdot 3 \pm 3 \cdot 7 \mathrm{nmol} / \mathrm{l}, \mathrm{N}=6)$. 
Table 1. The relative number of Leydig cells (per 1000 Sertoli cells) and the number of possible Leydig cell precursors after 16 days of daily treatment with hCG or FSH (1 or 2 injections per day, respectively)

\begin{tabular}{lcc}
\hline Treatment & $\begin{array}{c}\text { Leydig } \\
\text { cells }\end{array}$ & $\begin{array}{c}\text { Possible } \\
\text { Leydig cell } \\
\text { precursors }\end{array}$ \\
\hline None (control) & $535 \pm 54$ & $1382 \pm 148$ \\
hCG & $874 \pm 107^{*}$ & $1174 \pm 93$ \\
FSH & $425 \pm 43$ & $1316 \pm 90$ \\
\hline
\end{tabular}

Values are mean \pm s.e.m. for 4 monkeys.

*Significantly different from control, $P<0.01$.

\section{Discussion}

In cynomolgus monkeys, daily hCG treatment for 16 days resulted in a significant $163 \%$ increase in the number of Leydig cells, and a 9-fold rise in plasma testosterone concentrations. The increase in plasma testosterone values was much higher than the rise in the number of Leydig cells, indicating that, in addition to a rise in cell numbers, the steroid production per Leydig cell was also stimulated after 16 days of hCG treatment.

The number of labelled Leydig cells after hCG treatment was very low, indicating that probably most new Leydig cells are formed as a result of differentiation of precursor cells, and that proliferation of Leydig cells does not play an important role in this process. This is in agreement with the results of de Kretser (1967) and Schulze (1984), who suggested that the increase in the number of Leydig cells in the adult human testis after hCG stimulation is caused exclusively by the development of precursor cells. On the other hand, Heller \& Leach (1971) reported an increase in Leydig cell volume, but did not observe an increase in Leydig cell number in men, even after 16 weeks of hCG treatment. These contradictory results may be explained by a difference in the dose of hCG administered per unit of body weight per week. In the present study the dose of hCG was $\sim 3$-fold higher than the dose used by Heller \& Leach (1971).

In adult rats, daily treatment with hCG stimulates a rapid differentiation of precursor cells into Leydig cells, as well as proliferation of Leydig cells. The number of proliferating Leydig cells was considerably higher in these animals (Teerds et al., 1988) than in the monkeys in the present study.

The number of interstitial cells incorporating $\left[{ }^{3} \mathrm{H}\right]$ thymidine in the present study was low, but not significantly different from that found by Fouquet \& Raynaud (1985). The number of possible precursor cells that could be calculated (see 'Materials and Methods') had slightly decreased after hCG treatment, although the number of possible precursor cells incorporating $\left[{ }^{3} \mathrm{H}\right]$ thymidine had slightly but significantly increased when compared with the control biopsies (Table 1). This is in contrast to findings for rats after 10 days of hCG treatment. In such rats the number of possible Leydig cell precursors increased approximately $27 \%$ and many proliferating cells were found (Teerds et al., 1988). These different results may be explained by differences in the dose of hCG: the daily dose of hCG administered to rats per unit of body weight was 4-5-fold higher than that which was given to the monkeys.

In immature hypophysectomized rats daily FSH treatment resulted in a rise in the number of Leydig cells, and an increase in plasma testosterone concentrations (Kerr \& Sharpe, 1985a, b; Teerds et al., 1989). In adult hypophysectomized rats, FSH treatment also caused a stimulation of Leydig cell function, such as steroidogenic enzyme activity, testosterone secretion and LH-receptor numbers (El Safoury \& Bartke, 1974; McNeilly et al., 1979; Shaw et al., 1979). Effects of FSH treatment on Leydig cell function in intact mature rats, however, have not yet been reported. 
Similarly, FSH treatment in adult cynomolgus monkeys did not have any effect on the number of Leydig cells or plasma testosterone values.

In contrast to the absence of effects of FSH on interstitial cells, van Alphen et al. (1988) showed, in the same adult cynomolgus monkeys, that daily FSH treatment resulted in a $200 \%$ increase in the number of spermatogonia. On the other hand, spermatogonial multiplication was not affected by treatment with hCG (van Alphen et al., 1988), which had such profound effects on interstitial cells.

We thank Dr J. W. Netto (Laboratory of Comparative Physiology, Utrecht, The Netherlands) and Dr R. Boot (National Institute of Public Health and Environmental Protection, Bilthoven, The Netherlands) for the monkeys; Dr F. H. de Jong for measuring the testosterone concentrations; Dr M. M. A. van Alphen, Dr J. van Vliet and Mr R. Dol for their assistance during the operations; Mr A. van Arnhem and Mr H. Westland for tending the monkeys and organizing the operations; Mr A. N. van Rijn for the photograph; and Dr A. Boudens for editorial help. This work was supported by the Dutch Foundation for Medical Research (Medigon), the J.A. Cohen Institute for Radiopathology and Radiation Protection, and Pharma Import BV/Serono, Haarlem, The Netherlands.

\section{References}

Chemes, H.E., Rivarola, M.A. \& Bergada, C. (1976) Effect of hCG on the interstitial cells and androgen production in the immature rat testis. J. Reprod. Fert. 46, 279-282.

Chemes, H.E., Gottlieb, S.E., Pasqualini, E., Domenchini, A., Rivarola, M.A. \& Bergada, C. (1985) Response to acute hCG stimulation and steroidogenic potential of Leydig cell fibroblastic precursors in humans. $J$. Androl. 6, 102-112.

Christensen, A.K. \& Peacock, K.C. (1980) Increase in Leydig cell number in the testes of adult rats treated chronically with an excess of human chorionic gonadotropin. Biol. Reprod. 22, 383-391.

de Kretser, D.M. (1967) Changes in the fine structure of the human testicular interstitial cells after treatment with human gonadotropins. Z. Zellforsch, mikrosk. Anat. 83, 344-358.

El Safoury, S. \& Bartke, A. (1974) Effects of folliclestimulating hormone and luteinizing hormone on plasma testosterone levels in hypophysectomized and in intact immature and adult male rats. J. Endocr. 61, 193-198.

Fouquet, J.P. \& Raynaud, F. (1985) Renewal of Leydig cells in the neonatal and adult monkey: a radioautographic study. Biol. Cell 54, 187-190.

Heller, C.G. \& Leach, D.R. (1971) Quantification of Leydig cells and measurement of Leydig cell size following administration of human chorionic gonadotropin to normal men. J. Reprod. Fert. 25, 185-192.

Heller, C.G., Calli, M.F., Pearson, J.E. \& Leach, D.R. (1971) Method for quantification of Leydig cells in man. J. Reprod. Fert. 25, 177-184.

Kerr, J.B. \& Sharpe, R.M. (1985a) Stimulatory effect of follicle-stimulating hormone on rat Leydig cells. A morphometric and ultrastructural study. Cell Tissue Res. 239, 405-415.

Kerr, J.B. \& Sharpe, R.M. (1985b) Follicle-stimulating hormone induction of Leydig cell maturation. Endocrinology 116, 2592-2604.
Kluin, Ph.M., Kramer, M.F. \& de Rooij, D.G. (1983) Testicular development in Macaca irus after birth. Int. J. Androl. 6, 25-43.

McNeilly, A.S., de Kretser, D.M. \& Sharpe, R.M. (1979) Modulation of prolactin, luteinizing hormone (LH) and follicle-stimulating hormone (FSH) secretion by LHRH and bromocryptine (CB154) in the hypophysectomized pituitary grafted male rat and its effect on testicular LH-receptors and testosterone output. Biol. Reprod. 21, 141-147.

Nankin, H.R., Murono, E., Lin, T. \& Osterman, J. (1980) Morning and evening human Leydig cell response to hCG. Acta endocr., Copenh. 95, 560-567.

Saez, J.M. \& Forest, M.G. (1979) Kinetics of human chorionic gonadotropin-induced steroidogenic response of the human testis. I-Plasma testosterone: implications for human chorionic gonadotropin stimulation test. J. clin. Endocr. Metab. 49, 278-285.

Schulze, C. (1984) Sertoli cells and Leydig cells in man. Adv. Anat. Embryol. Cell. Biol. 88, 1-104.

Shaw, M.J., Georgopoulos, L.E. \& Payne, A.H. (1979) Synergistic effect of follicle-stimulating hormone and

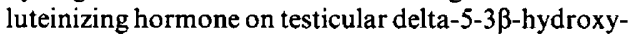
steroid dehydrogenase-isomerase: Application of a new method for the separation of testicular compartments. Endocrinology 104, 912-918.

Smals, A.G.H., Pieters, G.F.F.M., Drayer, J.I.M., Benraad, T.J. \& Kloppenborg, P.W.C. (1979) Leydig cell responsiveness to single and repeated human chorionic gonadotropin administration. $J$. clin. Endocr. Metab. 49, 12-19.

Steinberger, A. \& Steinberger E. (1977) The Sertoli cells. In The Testis, vol. IV, pp. 371-399. Eds A. D. Johnson \& W. R. Gomes. Academic Press, New York.

Teerds, K.J., de Rooij, D.G., Rommerts, F.F.G. \& Wensing, C.J.G. (1988) The regulation of the proliferation and differentiation of Leydig cell precursor cells after EDS administration or daily hCG treatment. $J$. Androl. 9, 343-351. 
Teerds, K.J., Closset, J., Rommerts, F.F.G., de Rooij, D.G., Stocco, D.M., Colenbrander, B., Wensing, C.J.G. \& Hennen, G. (1989) Effects of pure FSH and LH preparations on the number and function of Leydig cells in immature hypophysectomized rats. $J$. Endocr. 120, 97-106.

van Alphen, M.M.A., van der Kant, H.J.G. \& de Rooij, D.G. (1988) Follicle-stimulating hormone stimulates spermatogenesis in the adult monkey. Endocrinology 123, 1449-1450.

Verjans, J.L., Cooke, B.A., de Jong, F.H., de Jong, C.C.M. \& van der Molen, H.J. (1973) Evaluation of a radioimmunoassay for testosterone estimation. $J$. Steroid Biochem. 4, 665-676.

Received 5 December 1988 